\title{
MODEL PEMBELAJARAN TWO STAY TWO STRAY DAN HASIL BELAJAR KOGNITIF
}

\author{
Fitrianti; STKIP PGRI Papua \\ Supardi U.S. $\bowtie$; Universitas Indraprasta PGRI
}

\begin{abstract}
This study aims to analyze the effect of the Two Stay Two Stray learning model on cognitive learning outcomes for the Diversity of Living Things and Their Conservation Efforts. The research was conducted by using a quasiexperimental method on seventh grade students of SMPN in Serang Regency, Banten Province. The research data were analyzed using statistics of descriptive and $t$-test inferential. The results showed that the cognitive learning outcomes who were taught using conventional learning models had an average score of 7 1.7; while for students who used the Two Stay Two Stray learning model obtained an average score of 78.8. The results of inferential analysis obtained $t$-count $=3.694$ higher than $t$-table $=1.729$ so that it can be concluded that there is a significant effect of the Two Stay Two Stray learning model on the cognitive learning outcomes of the Diversity of Living Things and Their Conservation Efforts. In order to improve student cognitive learning outcomes, teachers should use the Two Stay Two Stray model in the learning process in the classroom.
\end{abstract}

Keywords: Two Stay Two Stray Learning, Diversity of Living Things and Their Conservation Efforts, Cognitive Learning Outcomes.

supardius77@gmail.com

Citation: Fitriyanti, F., \& Supardi, S.U. (2021). Model Pembelajaran Two Stay Two Stray dan Hasil Belajar Kognitif. Social Sciences, Humanities and Education Journal (SHE Journal), 2(1), 38 - 46. DOI: $10.25273 /$ she.v2i1.8549

\section{(c) BY-NC-SA}

Published by Universitas PGRI Madiun. This work is licensed under the Creative Commons AttributionNonCommercial-ShareAlike 4.0 International License. 


\section{PENDAHULUAN}

Dewasa ini dunia pendidikan dihadapkan pada tantangan yang mengharuskan mampu melahirkan sumber daya manusia (SDM) yang dapat memenuhi tuntutan global. Pendidikan merupakan suatu wadah kegiatan yang berusaha untuk membangun masyarakat dan watak bangsa secara berkesinambungan, yaitu membina mental, rasio, intelektual dan kepribadian dalam rangka manusia seutuhnya. Oleh karena itu, pendidikan perlu mendapat perhatian, penanganan, dan prioritas secara intensif dari pemerintah, masyarakat, maupun pengelola pendidikan. Terlebih lagi dewasa ini yang saat ini kita sedang dilanda wabah pandemi virus corona Covid-19.

Sebagai salah satu mata pelajaran yang diajarkan di sekolah, ilmu pengetahuan alam (IPA) merupakan bagian yang tidak terpisahkan dari ilmu pengetahuan lainnya. IPA merupakan salah satu ilmu dasar yang mempunyai peranan penting dalam upaya penguasaan ilmu pengetahuan dan teknologi, dan penerapan pendidikannya mulai dari sekolah dasar sampai dengan perguruan tinggi. Dengan adanya mata pelajaran IPA pada semua jenjang pendidikan, diharapkan siswa dapat berpikir logis, kritis, rasional, kreatif dan percaya diri. Namun sangat disayangkan, karena sampai saat ini permasalahan yang menjadi rahasia umum di dunia pendidikan adalah hasil belajar IPA ranah kognitif masih rendah.

Hasil belajar adalah pola-pola perubahan tingkah laku seseorang yang meliputi aspek kognitif, afektif dan psikomotor setelah menempuh kegiatan belajar yang tingkat kualitas perubahannya sangat ditentukan oleh faktor-faktor yang ada dalam diri siswa dan lingkungan sosial yang mempengaruhinya. Ada beberapa faktor yang mempengaruhi hasil belajar yaitu: faktor internal dan eksternal. Faktor internal adalah faktor yang ada di dalam diri individu dipengaruhi oleh dorongan dalam diri siswa untuk memahami cara belajar yang tepat bagi diri mereka sendiri yang sedang belajar, sedangkan faktor eksternal adalah faktor yang ada di luar individu. Dalam hal ini berupa penerapan model pembelajaran di kelas yang berhubungan dengan materi yang diajarkan. Oleh karena itu, keberhasilan proses pembelajaran juga bergantung pada siswa itu sendiri.

Rendahnya hasil belajar IPA ranah kognitif disebabkan oleh aktivitas dalam pembelajarannya yang masih sangat rendah. Hal ini dikarenakan pada pembelajaran IPA, siswa dituntut untuk banyak membaca karena sebagian besar pembelajarannya bersifat teoritik dan diperlukan hafalan mengenai bahasa latin. Siswa jarang sekali mengajukan pertanyaan walaupun guru telah memancing dengan pertanyaanpertanyaan yang sekiranya siswa belum jelas. Dalam proses pembelajaran selama ini, guru senantiasa mendominasi aktivitas di kelas, sementara siswa dijadikan sebagai objek untuk menerima hal-hal yang dianggap penting pada saat pembelajaran berlangsung. Berkaitan dengan hal tersebut, permasalahan yang sama juga terjadi di sekolah menengah pertama negeri (SMPN) di Kabupaten Serang Provinsi Banten, kegiatan pembelajarannya terpusat pada guru sehingga sebagian besar siswanya menjadi pasif. Kurangnya aktivitas siswa di dalam kelas dikarenakan penggunaan model pembelajaran yang tidak sesuai sehingga siswa kesulitan dalam memahami dan menguasai materi. Oleh karena itu, guru diharapkan memiliki kemampuan-kemampuan yang diperlukan siswa, menguasai materi yang akan diajarkan, mampu 
mengklasifikasikan macam-macam model pembelajaran dan menguasai teknik-teknik mengajar. Penentuan model pembelajaran bagi guru merupakan hal yang cukup penting.

Salah satu materi yang terdapat di kelas VII sekolah menengah pertama (SMP) yaitu keanekaragaman makhluk hidup dan upaya pelestariannya. Konsep ini dianggap sulit oleh siswa karena sangat membutuhkan pemahaman yang mendalam. Berdasarkan hasil observasi terhadap beberapa guru IPA SMPN di Kabupaten Serang, diketahui bahwa hasil pembelajaran IPA pada SMPN di Kabupaten Serang selama ini cukup baik secara akademik. Meskipun demikian, perlu dilakukan cara belajar yang lebih efektif seperti penggunaan model pembelajaran yang tepat sehingga dapat meningkatkan lagi pola berpikir kritis dan kreativitas siswa serta hasil belajar IPA, khususnya ranah kognitif. Selain itu, penulis juga melakukan wawancara terhadap beberapa siswa pada SMPN di Kabupaten Serang. Siswa yang diwawancarai tersebut berprestasi dan menjuarai Olympiade MIPA (matematika dan IPA) se-kabupaten Serang. Dia mengakui bahwa pada saat duduk di kelas VII untuk materi keanekaragaman makhluk hidup dan upaya pelestariannya membutuhkan tingkat pemahaman yang tinggi.

Salah satu model pembelajaran yang diduga dapat membuat siswa lebih aktif adalah model pembelajaran kooperatif tipe Two Stay Two Stray (TSTS). Model pembelajaran Two Stay Two Stray merupakan salah satu model yang menggunakan teknik diskusi yang berbasis cooperatif learning. "Model pembelajaran ini telah terbukti dapat dipergunakan dalam berbagai mata pelajaran dan berbagai usulan (Suyatno, 2009: 51)". Model pembelajaran Two Stay Two Stray (TS-TS) digunakan untuk mewujudkan kegiatan belajar yang berpusat pada siswa (student oriented), terutama untuk mengatasi permasalahan yang ditemukan oleh guru dalam mengaktifkan siswa yang tidak dapat bekerja sama dengan orang lain, siswa yang agresif dan tidak peduli pada orang lain. Dengan demikian, pembelajaran dengan model pembelajaran Two Stay Two Stray murni berorientasi pada aktivitas belajar siswa menjadi lebih bermakna, lebih berorientasi pada keaktifan, serta membantu meningkatkan proses dan hasil belajar siswa.

Berdasarkan fenomena di atas, maka penelitian ini bertujuan untuk mengetahui dan menganalisis pengaruh model pembelajaran Two Stay Two Stray terhadap hasil belajar kognitif Keanekaragaman Makhluk Hidup dan Upaya Pelestarianya. Variabel terikat dalam penelitian ini adalah Hasil belajar Kognitif Keanekaragaman Makhluk Hidup dan Upaya Pelestariannya. Variabel terikat yang akan dianalisis ini merupakan bagian dari hasil belajar mata pelajaran Ilmu Pengetahuan Alam (IPA) siswa Sekolah Menenngah Pertama (SMP) Kelas VII.

\section{METODE}

Penelitian ini menggunakan jenis penelitian kuantitatif dengan metode penelitian berbentuk kuasi eksperimen. Dalam penelitian ini, peneliti memberikan jenis perlakuan yang berbeda pada dua kelompok belajar siswa. Kelompok yang satu dijadikan sebagai kelompok eksperimen yaitu kelompok yang diberikan perlakuan menggunakan model pembelajaran Two Stay Two Stray, sedangkan kelompok lainnya sebagai kelompok kontrol yang diberikan perlakuan dengan menggunakan model pembelajaran konvensional, yaitu pembelajaran dengan ekspositori dan tanya jawab. Setelah selesai perlakuan, pada dua 
kelompok belajar tersebut diberi tes yang sama. Hasil dari tes tersebut dijadikan data penelitian dan dianalisis. Penelitian eksperimen ini menggunakan desain static group comparison. Desain penelitian disusun untuk dapat membandingkan hasil belajar kedua kelompok setelah diberi perlakuan yang berbeda, yaitu kelompok eksperimen dan kelompok kontrol. Adapun diagram desain penelitiannya sebagai berikut.

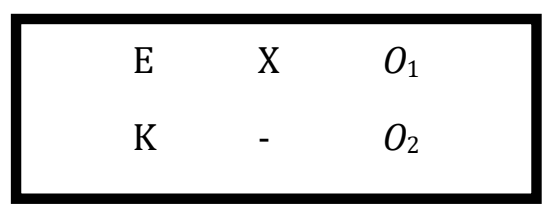

Gambar 1. Diagram Desain Penelitian

Keterangan:

E : Kelompok Eksperimen

$\mathrm{K}$ : Kelompok Kontrol

$\mathrm{X}$ : Siswa yang diajar dengan model pembelajaran Two Stay Two Stray

- : Siswa yang diajar dengan model pembelajaran konvensional

$O$ : Hasil belajar yang diajar dengan

1 model pembelajaran Two Stay Two Stray

$O$ : Hasil belajar yang diajar dengan

2 model pembelajaran konvensional

Dalam penelitian ini, siswa tidak mengetahui bahwa mereka sedang berada dalam kondisi eksperimen. Guru diharapkan tidak menunjukan perbedaan sikap diantara kedua kelas yang dijadikan percobaan (sampel penelitian) dari tujuh kelas.

Sebelum memberikan perlakuan, guru melakukan pematangan konsep yang berkaitan dengan perlakuan. Adapun desain pembelajarannya dibuat sama untuk kelas yang dijadikan percobaan (sampel penelitian) termasuk suasana kelas dan fasilitas tiap kelas, yang membedakan hanyalah model pembelajaran dan sumber belajar diantara kedua kelas percobaan tersebut.
Setelah dilakukan perlakuan, maka pada pertemuan terakhir dilakukan tes untuk memperoleh data hasil belajar. Peneliti mengumpulkan data dari kelompok eksperimen dan kontrol dengan memberikan soal tes objektif pilihan ganda sebanyak 30 soal yang sebelumnya telah divalidasi.

Penelitian dilaksanakan pada siswa sekolah menengah pertama negeri (SMPN) Kelas VII di Kabupaten Serang, Provinsi Banten, Republik Indonesia. Dalam penelitian ini diambil sampel sebanyak 40 orang siswa yang terdistribusi untuk masing-masing kelompok sebanyak 20 orang. "Sampel adalah sebagian dari populasi yang diambil sebagai sumber data dan dapat mewakili seluruh populasi" (Riduwan, 2007 : 56). Oleh karena itu, sampel diperlukan untuk pengambilan data yang dapat menggambarkan keadaan populasi sebenarnya. Untuk pengambilan sampel penelitian ini, siswa-siswa yang tergabung dalam populasi terjangkau diambil dua kelas secara acak, yaitu 1 (satu) kelas untuk diberi perlakuan model pembelajaran Two Stay Two Stray, dan 1 (satu) kelas berikutnya untuk diberi perlakuan model pembelajaran konvensional.

Analisis data yang digunakan meliputi analisis deskriptif, pengujian persyaratan analisis, dan analisis inferensial untuk pengujian hipotesis penelitian. Analisis deskriptif dilakukan untuk menyajikan, mendeskripsikan, serta mengkomunikasikan data penelitian dalam bentuk tabel, gambar atau grafik, dan ukuran-ukuran pusat, letak, dan simpangan seperti mean, modus, median, dan simpangan baku. Dikarenakan uji hipotesis yang digunakan dalam penelitian ini adalah uji beda dua rata-rata dengan statistika uji$t$, maka disyaratkan datanya harus berdistribusi normal dan antar kelompok harus memiliki varian yang homogen. Pengujian normalitas data dilakukan dengan teknik uji Lillifors, sedangkan uji homogenitas varian menggunakan teknik uji-F (uji Fisher). 
Sedangkan dalam pengujian hipotesis penelitian mengguakan statistika inferensial dengan Teknik Uji Beda Dua Rerata melalui Uji-t dengan taraf signifikansi $a=0,05$.

\section{HASIL PENELITIAN DAN PEMBAHASAN}

\section{Hasil Penelitian}

Data hasil belajar siswa merupakan skor hasil belajar kognitif Keanekaragaman Makhluk Hidup dan Upaya Pelestarianya siswa yang diajarkan dengan model pembelajaran Two Stay Two Stray (kelas eksperimen) dan model pembelajaran konvensional (kelas kontrol). Skor hasil belajar kognitif siswa diperoleh dari pengerjaan soal pilihan ganda sebanyak 30 item dengan 4 pilihan jawaban dari A sampai D.

Skor Hasil Belajar Kognitif Keanekaragaman Makhluk Hidup dan Upaya Pelestarianya Siswa Kelas Eksperimen

Dari hasil analisis ukuran pusat, letak dan simpangan diperoleh mean (rerata) $=78,8$; median $=82,5$; modus $=88,5$; dan simpangan baku $=4,6$. Gambaran ini menujukkan bahwa hasil belajar kognitif Kenekaragaman Makhluk Hidup dan Upaya Pelestariannya pada kelompok Eksperimen tergolong tinggi.

Dalam bentuk grafis, data hasil belajar kognitif kelompok eksperimen dapat dilihat seperti histogram dan poligon berikut.

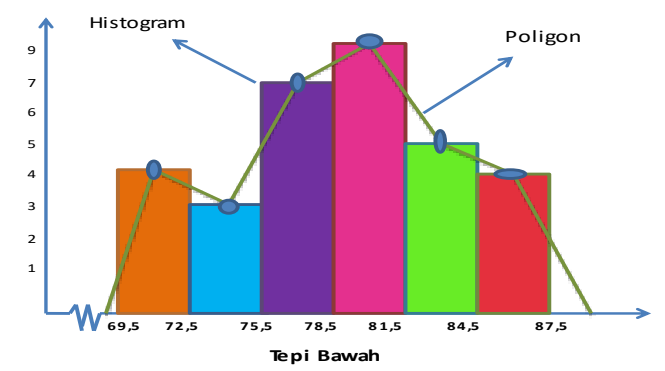

Gambar 4. Histogram dan Poligon Skor Hasil Belajar Kognitif Siswa Kelas Eksperimen (Twi Stay Two Stray)
Skor Hasil Belajar Kognitif Keanekaragaman Makhluk Hidup dan Upaya Pelestarianya Siswa Kelas Kontrol

Dari hasil analisis ukuran pusat, letak dan simpangan diperoleh mean (rerata) $=71,7$; median $=74,3$; modus $=69,0 ;$ dan simpangan baku $=5,95$. Gambaran ini menujukkan bahwa hasil belajar kognitif Kenekaragaman Makhluk Hidup dan Upaya Pelestariannya pada kelompok Eksperimen tergolong sedang.

Dalam bentuk grafis, data hasil belajar kognitif kelompok eksperimen dapat dilihat seperti histogram dan poligon berikut.

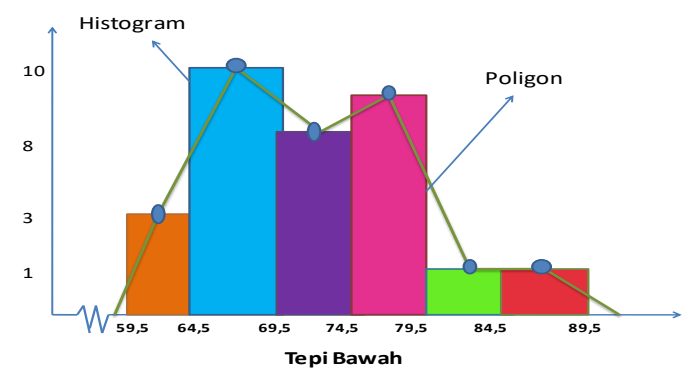

Gambar 5. Histogram dan Poligon Skor Hasil Belajar Kognitif Siswa Kelas Kontrol

(Konvensional)

Hasil pengujian normalitas data pada kelompok eksperimen dan kelompok kontrol dengan statistika Teknik Uji Lilliefors diperoleh hasil seperti tabel 3.

Sementara hasil pengujian homogenitas varian antara kelompok eksperimen dan kelompok kontrol dengan statistika Teknik Uji-F diperoleh hasil seperti table 4 .

Gambaran deskriptif data hasil belajar kognitif Keanekaragaman Makhluk Hidup dan Upaya Pelestarianya siswa kelas VII SMPN di Kabupaten Serang Provinsi Banten untuk kelompok eksperimen dan kelompok kontrol secara ringkas dapat dilihat pada tabel 5 .

Hasil perhitungan dengan statistika uji beda dua rata-rata melalui teknik Uji-t diperoleh harga $\mathrm{t}$-hitung $=$ 3,694 . Sementara, harga $t$-tabel untuk $\alpha=$ 0.05 dan $d k=n-1=20-1=19$ adalah 1,729. Oleh karena itu, dapat diketahui 
bahwa nilai t-hitung $>t_{\text {-tabel }}(3,694>1,729)$, maka dapat disimpulkan bahwa hasil pengujian signifikan menolak $\mathrm{HO}$ dan menerima $\mathrm{H} 1$, yang berarti nilai rata-rata nilai hasil belajar kognitif Keanekaragaman Makhluk Hidup dan Upaya Pelestariannya untuk kelas eksperimen lebih tinggi dibandingkan dengan kelas kontrol.

Hal ini menunjukkan bahwa adanya perbedaan yang signifikan atau nyata dari pemberian pengajaran dengan model pembelajaran Two Stay Two Stray dibandingkan dengan model pembelajaran konvensional. Dengan kata lain, bahwa secara signifikan terdapat pengaruh model pembelajaran Two Stay Two Stray terhadap hasil belajar kognitif IPA untuk materi keanekaragaman makhluk hidup dan upaya pelestarianya pada siswa SMPN Kelas VII.

Tabel 1. Distribusi Frekuensi Data Kelas Eksperimen (Two Stay Two Stray)

\begin{tabular}{|c|c|c|c|c|c|c|c|c|c|}
\hline $\begin{array}{c}\text { Kelas } \\
\text { Interval }\end{array}$ & fi & $x i$ & $f r$ & $f \%$ & $<\left(f k u m^{*}\right)$ & $>\left(\right.$ fkum $\left.^{* *}\right)$ & fi.xi & $\begin{array}{l}(x i- \\
x) 2\end{array}$ & $\begin{array}{l}f(x i- \\
x) 2\end{array}$ \\
\hline $70-72$ & 4 & 71 & 0,13 & 13 & 4 & 32 & 284 & 61 & 243 \\
\hline $73-75$ & 3 & 74 & 0,09 & 9 & 7 & 28 & 222 & 23 & 69 \\
\hline $76-78$ & 7 & 77 & 0,22 & 22 & 15 & 25 & 539 & 3 & 23 \\
\hline $79-81$ & 9 & 80 & 0,28 & 28 & 23 & 17 & 720 & 1 & 13 \\
\hline $82-84$ & 5 & 83 & 0,16 & 16 & 28 & 9 & 415 & 18 & 88 \\
\hline $85-87$ & 4 & 86 & 0,13 & 13 & 32 & 4 & 344 & 52 & 207 \\
\hline$\Sigma$ & 32 & & 1 & 100 & & & 2524 & & 644 \\
\hline
\end{tabular}

Tabel 2. Distribusi Frekuensi Data Kelas Kontrol (Konvensional)

\begin{tabular}{|c|c|c|c|c|c|c|c|c|c|}
\hline $\begin{array}{c}\text { Kelas } \\
\text { Interval }\end{array}$ & $F i$ & $x i$ & $f r$ & $f \%$ & $<\left(\right.$ fkum $\left.^{*}\right)$ & $>\left(f k u m^{* *}\right)$ & fi.xi & $\begin{array}{l}(x i- \\
x) 2\end{array}$ & $\begin{array}{c}f(x i- \\
x) 2\end{array}$ \\
\hline $60-64$ & 3 & 62 & 0,09 & 9 & 3 & 32 & 186 & 94 & 282 \\
\hline $65-69$ & 10 & 67 & 0,31 & 31 & 13 & 29 & 670 & 22 & 221 \\
\hline $70-74$ & 8 & 72 & 0,25 & 25 & 21 & 19 & 576 & 0 & 1 \\
\hline $75-79$ & 9 & 77 & 0,28 & 28 & 30 & 11 & 693 & 28 & 253 \\
\hline $80-84$ & 1 & 82 & 0,03 & 3 & 31 & 2 & 82 & 106 & 106 \\
\hline $85-89$ & 1 & 87 & 0,03 & 3 & 32 & 1 & 87 & 234 & 234 \\
\hline$\Sigma$ & 32 & & 1 & 100 & & & 2294 & & 1097 \\
\hline
\end{tabular}

Tabel 3. Hasil Uji Normalitas Skor Hasil Belajar Kognitif Siswa

\begin{tabular}{cccccc}
\hline Kelompok & $\boldsymbol{n}$ & $\boldsymbol{\alpha}$ & Lo & L-tabel & KEPUTUSAN \\
\hline Eksperimen & 20 & 0,05 & 0,122 & 0,190 & $\begin{array}{c}\text { Data pada kedua kelompok } \\
\text { penelitian berdistribusi } \\
\text { Kontrol }\end{array}$ \\
\hline
\end{tabular}

Tabel 4. Hasil Uji Homogenitas antar Kelompok Data Penelitian

\begin{tabular}{cccccc}
\hline $\mathbf{K}$ & $\mathbf{d k}$ & $\boldsymbol{\alpha}$ & $\mathbf{F}$-hitung & $\mathbf{F}$-tabel & KESIMPULAN \\
\hline 2 & 9 & 0,05 & 0,77 & 3,18 & $\begin{array}{c}\text { Varian Kedua kelompok } \\
\text { data homogen }\end{array}$ \\
\hline
\end{tabular}

Tabel 5. Data Deskriptif Skor Hasil Belajar Kognitif Keanakaragaman Makhluk Hidup dan Upaya pelestariannya

\begin{tabular}{ccc}
\hline \multirow{2}{*}{ Kelompok } & \multicolumn{2}{c}{ Skor Hasil Belajar Kognitif Siswa Kelas VII } \\
\cline { 2 - 3 } & Eksperimen & Kontrol \\
\hline$n$ & 20 & 20 \\
$\bar{x}$ & 78,8 & 71,7 \\
$s$ & 4,60 & 5,95 \\
\hline
\end{tabular}




\section{PEMBAHASAN}

Hasil penelitian menyimpulkan, terdapat pengaruh model pembelajaran Two Stay Two Stray terhadap hasil belajar kognitif Keanekaragaman Makhluk Hidup dan Upaya Pelestariannya. Hal ini didukung dengan fakta hasil perhitungan dan pengujian hipotesis menggunakan Statistika Uji-t, diperoleh hasil $\mathrm{t}$-hitung $=$ 3,694 lebih tinggi dari pada $t_{\text {-tabel }}=1,729$. Hasil tersebut menunjukkan bahwa hasil belajar kognitif Keanekaragaman Makhluk Hidup dan Upaya Pelestariannya.dengan model pembelajaran Two Stay Two Stray lebih tinggi dibandingkan dengan model pembelajaran konvensional yang berupa ekspositori dan tanya jawab semata. Model pembelajaran Two Stay Two Stray mempunyai kelebihan-kelebihan yang dapat mengasah proses berpikir, berorganisasi, dan berargumentasi dalam kegiatan pembelajaran.

Hasil penelitian tersebut juga didukung dengan data deskriptif. Hasil belajar kognitif Keanekaragaman Makhluk Hidup dan Upaya Pelestariannya pada kelompok eksperimen (dengan model pembelaran Two Stay Two Stray) diperoleh skor ratarata 78,8 , median 82,5 , modus 88,5 , dan simpangan baku 4,6. Sedangkan hasil belajar kognitif Keanekaragaman Makhluk Hidup dan Upaya Pelestariannya pada kelompok kontrol diperoleh skor rata-rata 71,7 , median 74,3, modus 69, dan simpangan baku 5,95. Secara deskriptif, diketahui bahwa skor rata-rata kelas ekperimen (model pembelajaran Two Stay Two Stray) lebih tinggi daripada kelas kontrol (model pembelajaran Konvensional) dengan selisih 7,1 poin.

Hasil penelitian ini sejalan dengan temuan (Nugraheni dkk, 2017: 56) yang juga menyimpulkan terdapat pengaruh model pembelajarn kooperatif Two Stay Two Stray terhadap hasil belajar siswa. Hanya saja penelitian ini dilakukan pada siswa Sekolah Menengah Kejuruan untuk mata pelajaran
Pekerjaan Dasar Teknik Otomotif. Lebih lanjut (Nugraheni dkk, 2017: 56) mengatakan bahwa model pembelajaran kooperaif Two Stay Two Stray merupakan model pembelajaran yang dapat merangsang siswa untuk lebih aktif bertanya, menyiapkan diri untuk siap belajar, bekerja kelompok dan bekerjasama dalam memecahkan masalah. Melalui pembelajaran kooperatif ini juga dapat melatih siswa untuk lebih berani dalam mengemukakan pendapat dan percaya diri.

Hal serupa disampaikan oleh Febriyanti, dkk (2014 : 9), menyatakan bahwa terdapat perbedaan hasil belajar yang signifikan antara siswa yang pembelajarannya menggunakan model Two Stay Two Stray (TS-TS) berbantuan media konkret dengan yang belajar menggunakan model konvensional. Hasil belajar siswa yang menggunakan pembelajaran Two Stay Two Stray (TSTS) berbantuan media konkret berada pada kategori sangat tinggi, sedangkan hasil belajar siswa yang menggunakan pembelajaran konvensional berada pada kategori sedang. Penelitian yang dilakukan oleh Febriyanti, dkk (2014: 4) dilakukan pada pelajaran Matematika dan dilakukan pada siswa Sekolah Dasar Kelas V.

Hasil penelitian yang dilakukan pada siswa kelas IV Sekolah Dasar Negeri di Gugus 01 Sidoarjo juga menyimpulkan bahwa model pembelajaran Two Stay Two Stray pada materi sumber energi alternatif memiliki pengaruh terhadap hasil belajar siswa (Fitrianingrum dan Ulhaq, 2018: 953). Penerapan model pembelajaran kooperatif tipe Two Stay Two Stray mampu menciptakan suasana belajar yang menyenangkan. Saat dilakukan pengelompokan, proses pembelajaran tidak meninggalkan esensi belajar dengan cara siswa berbagi pengetahuan dan pengalaman dengan kelompok lain. Ciri utama model pembelajaran ini dilakukan secara kelompok dan ada proses berbagi. 
Secara singkat sintak pembelajaran Two Stay Two Stray: (a) siswa dibagi dalam beberapa kelompok beranggota 4-5 orang, siswa bekerja di dalam kelompok untuk membahas materi diberikan guru; (b) kemudian dua orang dari tiap kelompok akan berkunjung ke kelompok lain (stray) untuk mencatat hasil pembahasan materi dari kelompok lain, dan (c) sisa anggota kelompok tetap di kelompoknya (stay) untuk menerima yang bertamu ke kelompoknya dan menjelaskan materi kelompok mereka; serta (d) siswa yang bertamu diminta utuk kembali ke kelompoknya untuk menyampaikan hasil diskusi dari setiap perwakilan kelompok membacakan hasil diskusinya. Guru dan siswa bersama-sama menarik kesimpulan tentang pembelajaran pada pertemuan tersebut. Pada model ini tampaknya sebagai sesuatu yang terdiri atas berbagai komponen yang meliputi pengajaran langsung oleh guru, penggunaan buku panduan pelajaran, latihan-latihan formal, maupun kegiatankegiatan lainnya. Sumber belajar juga bisa berasal dari gambar, slide, hasil karya, internet, dan artikel, sehingga siswa menjadi lebih kreatif dan aktif untuk mendapatkan sumber belajar.

Model pembelajaran konvensional lebih sering mengggunakan pemberian informasi, dibandingkan dengan memperagakan dan memberikan kesempatan untuk menampilkan unjuk kerja secara langsung. Guru berasumsi bahwa keberhasilan program pembelajaran dilihat dari ketuntasannya menyampaikan seluruh materi yang ada dalam kurikulum. Penekanan aktivitas belajar lebih banyak pada buku teks dan kemampuan mengungkapkan kembali isi buku teks tersebut. Jadi, pembelajaran konvensional kurang menekankan pada pemberian keterampilan proses (handon activities).

Dengan demikian, sehingga dapat dipahami jika terdapat perbedaan hasil belajar kognitif Keanekaragaman Makhluk Hidup dan Upaya Pelestarianya antara siswa yang menggunakan model pembelajaran Two Stay Two Stray dengan yang menggunakan model pembelajaran konvensional. Dalam hal ini, hasil belajar siswa yang menggunakan model pembelajaran Two Stay Two Stray lebih efektif dari pada yang menggunakan model pembelajaran konvensional. dalam mata pelajaran IPA materi keanekaragaman makhluk hidup dan upaya pelestariannya. Gambaran ini menunjukkan terdapat pengaruh model pembelajaran Two Stay Two Stray terhadap hasil belajar kognitif Keanekaragaman Makhluk Hidup dan Upaya Pelestarianya.

\section{SIMPULAN}

Berdasarkan hasil analisis deskrptif dapat disimpulkan bahwa, hasil belajar kognitif Keanekaragaman Makhluk Hidup dan Upaya Pelestaraiannya pada pelajaran IPA, siswa kelas VII Sekolah Menengah Pertama (SMP) yang diajarkan dengan model pembelajaran konvensional mempunyai skor rata-rata 71,7; sedangkan untuk siswa yang menggunakan model pembelajaran Two Stay Two Stray diperoleh skor rata-rata 78,8 . Sehingga terdapat perbedaan ratarata skor hasil belajar kognitif dengan selisih 7,1. Sementara hasil analisis inferensial dengan Statistika Uji-t diperoleh hasil nilai t-hitung $=3,694$ lebih tinggi dari pada $t_{\text {-tabel }}=1,729$ sehingga dapat disimpulkan bahwa secara signifikan terdapat pengaruh model pembelajaran Two Stay Two Stray terhadap hasil belajar Kognitif Keanekaragaman Makhluk Hidup dan Upaya Pelestariannya pada siswa SMP kelas VII.

Hasil penelitian menyimpulkan bahwa model pembelaajaran Two Stay Two stray efektif dalam meningkatkan hasil belajar kognitif dalam pelajaran IPA dengan materi pokok Keanekaragaman Makhluk Hidup dan Upaya pelestariannya pada jenjang siswa SMP Kelas VII. Untuk itu sebagai implikasi dari hasil penelitian ini, maka hendaknya para guru mengimplementasikan model 
Two Stay Two Stray dalam proses pembelajaran di kelas agar hasil belajar kognitif IPA siswa SMP dapat meningkat. Oleh karenanya, agar model two stay two stray dapat diimplementasikan dalam proses pembelajaran IPA dikelas, ada beberapa hal yg diekomendasikan untuk segera dilakukan, antara lain: (a) para guru IPA hendaknya segera dilatih tentang model pembelajaran Two Stay Two Stray; (b) manajemen sekolah menyiapkan sarana dan prasarana untuk menunjang keterlaksaan proses pembelajaran dengan model Two Stay Two Stray; dan (c) bagian kurikulum agar mendesain jadwal pembelajaran di sekolah yang memungkinkan untuk dilaksanakannya model pembelajaran Two Stay Two Stray di kelas.

Hasil penelitian menunjukkan bahwa model pembelajaran Two Stay Two Stray efektif dalam meningkatkan hasil belajar kognitif IPA pada materi pokok Keanekaragaman Makhluk Hidup dan Upaya pelestariannya pada siswa jenjang SMP kelas VII. Untuk mendapatkan hasil penelitian yang lebih komprehensif, penulis menyarankan beberapa hal sebagai berikut:

1. Hendaknya dapat diteliti hasil belajar kognitif IPA untuk materi pokok lainnya (selain Keanekaragaman Makhluk Hidup dan Upaya Pelestariannya);

2. Hendaknya dapat diteliti hasil belajar kognitif pada mata pelajaran lainnya, selain IPA;

3. Hendaknya dapat diteliti hasil belajar IPA untuk ranah hasil belajar lainnya, seperti sikap social, sikap religious, maupun ketrampilan.

\section{DAFTAR PUSTAKA}

Febriyanti, Eka Andi Wrisca. I Nyoman Jampel. Syahruddin. (2014). Pengaruh Metode Pembelajaran Two Stay Two Stray Berbantuan Media Konkret Terhadap Hasil Belajar Siswa Kelas V. Jurnal Mimbar PGSD Universitas Pendidikan Ganesha Jurusan PGSD, 2(1), 1-10. https://ejournal.undiksha.ac.id/in dex.php/JJPGSD/article/view/354 $0 / 2859$

Fitrianingrum, Wulan Suci. Ulhaq Zuhdi. (2018). Pengaruh Model Pembelajaran Two Stay Two Stray Terhadap Hasil Belajar IPA pada Siswa Kelas IV. Jurnal Penelitian PGSD, 06(06), 945-954. https://www.neliti.com/publicati ons $/ 255089 /$ pengaruh-modelpembelajaran-two-stay-two-strayterhadap-hasil-belajar-ipa-pada-s

Nugraheni, Novia. Harlin. Zulherman. (2017). Pengaruh Model Pembelajaran Two Stay Two Stray Terhadap Hasil Belajar Pada Mata Pelajaran Pekerjaan Dasar Teknik Otomotif Siswa Kelas X TKR di SMK Negeri 2 Palembang. Jurnal Pendidikan Teknik Mesin, 4(1), 5158.https://ejournal.unsri.ac.id/in dex.php/ptm/article/download/5 $424 / 3629$

Riduwan. (2007). Belajar Mudah Penelitian Guru-Karyawan dan Peneliti. Bandung: Alfabeta.

Suyatno. (2009). Menjelajah Pembelajaran. Surabaya: Masmedia Buana Pustaka. 